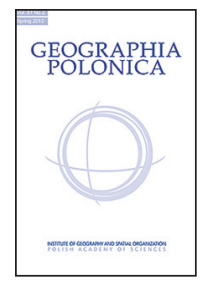

\title{
SPATIAL GROWTH OF URBANISED LAND WITHIN THE WARSAW METROPOLITAN AREA IN THE FIRST DECADE OF THE 21ST CENTURY
}

\author{
Bożena Degórska \\ Institute of Geography and Spatial Organization \\ Polish Academy of Sciences \\ Twarda 51/55, 00-818 Warsaw: Poland \\ e-mail address: bodego@twarda.pan.pl
}

\begin{abstract}
The main objective of the study was to recognize the spatial regularities of the urbanised land development, as well as to determine the impact of the distance from the city center of Warsaw on the ongoing transformations. Research performed in the Warsaw Metropolitan Area (WMA) refers to the period of 2000-2010. Special stress was put on changes that had been taking place in rural areas, since Poland entered the EU. It was determined that there is ever greater relation between the distance from Warsaw and the development of urbanised areas. The study showed, that the most urbanised rural areas (gminas) are still those to the South-West of Warsaw, within the distance of up to $40 \mathrm{~km}$. Performed actions determined that since 2004, there had been changes in the geographical directions of intense urbanisation of the WMA area. While the southern and western parts of the city seemed to have lost their importance, the northern and eastern ones, on the other hand, seemed to had been gaining in significance.
\end{abstract}

\section{Key words}

urban growth • urban sprawl • urbanisation - suburbanisation - land use - Warsaw Metropolitan Area • Poland

\section{Introduction}

An intensified development of urbanisation processes in Poland has been among the ensuing consequences of the period of socioeconomic transformation experienced by the country from 1989 onwards. Nevertheless, a more dynamic urbanisation process only made itself felt after a certain time delay, the first phase of the transformation thus featuring a continuation of trends apparent in the 1980s involving a crisis with the construction of new housing. It was only in the second half of the 1990s that a revival of housebuilding took hold (Śleszyński 2012). Nevertheless, typical suburbia did not come into existence in the areas around Poland's large cities, there being instead a wide scattering of usually small housing estates, groups of several homes, or even single residential buildings, whose presence is a reflection of inadequate control over rapidly-developing areas of construction. The space taking shape at this point was of the kind in which inhabitants sought better quality of life, while making this feature almost entirely dependent on the possession of a car or cars. The literature most often dubs this state of affairs 'urban sprawl', or occasionally also 'suburban sprawl' (Batty et al. 2003). It is most marked in the areas surrounding the cores of metropolitan 
areas that are already in existence or are taking shape, and its characteristic feature in Polish circumstances is the very diffuse nature of the newlybuilt areas, to the extent that these often appear where there remains a lack of municipal infrastructure, notably water supply and sewerage, roads and public transport.

In Poland, as in the wider world, the spatial development of cities and urban sprawl have only really become subjects of more-numerous studies - and a great deal of academic debate - in the last few years. The work done has been either of a general, more theoretical, nature, or else has related to particular areas. The Warsaw Metropolitan Area (WMA) has been embraced by such studies on a number of occasions in recent years, inter alia in Chmielewski (2005), Degórska (2003, 2004, 2007, 2009, 2012), Degórska and Deręgowska (2008), Gruszecka (2005), Gutry-Korycka et al. (2005), Gzell (2002), Korcelli et al. (2012), Lisowski (2010), Mantey (2011), Nowakowski (2006), Strzelecki and Holcel (2008), Strzelecki and Kucińska (2006) and Śleszyński (2012). The topic has also fallen within more global research currents, these attaching ever greater importance to the shaping of new relations between such areas, as well as the patterns to urban growth (inter alia Abbott 2002; Aquayo et al. 2007; Ravetz 2000; Richardson \& Bae 2004). More and more work is also addressing the matter or urban growth's influence on the landscape (Antrop 2004; Cieslewicz 2002; Degórska 2009, 2012; Degórska \& Deręgowska 2008; Fagan et al. 2001; Korwel-Lejkowska 2006; Solon 2005, 2009; Trzaskowska \& Sobczak 2006).

It needs to be stressed that the demographic dimension which usually constitutes the main aspect to work on suburbanisation processes is not of itself sufficient these days to account for the phenomena ongoing around the large cities, since the growth of urbanised areas does not always go hand in hand with adequate population development. Moreover, Śleszyński (2012) was able to point to very marked disparities between the actual situation as regards population in Mazowieckie voivodship, the Warsaw agglomeration and Warsaw on the one hand, and the actual population as registered officially, on the other. It is for this reason among others that more and more weight is being attached to the spatial patterns of urban growth, and in this context particularly valuable information can be supplied by a focus on the spatial growth affecting urbanised land, in respect of both changes that have occurred to date and those that are anticipated.

The phenomenon of urban sprawl occurring in Poland (including in its WMA) has mechanisms that are now quite well-known and well-researched, in terms of their socioeconomic conditioning and consequences (inter alia Degórska 2004, 2009; Gzell et al. 2011; Korcelli et al. 2012; Lisowski 2005, 2007, 2008, 2010; Lisowski \& Grochowski 2008; Lorens 2003, 2005; Mantey 2007; Markowski \& Marszał 2006; Strzelecki \& Kucińska 2006; Zuziak 2005). However, what is much less fully accounted for is the spatial pattern characterising the process, even though some studies have focused on changes in land use and land cover (Degórska \& Deręgowska 2008; Gutry-Korycka et al. 2005; Solon 2005, 2009). What has been determined in this field so far is seen to represent an important thrust to research, since urban sprawl poses a huge threat to the sustainable development of functional urban areas, and metropolitan areas in particular, most especially when it comes to the spatial order and landscape harmony, as well as the prospects for ecosystem functioning and quality of life, and the social costs generated.

The work described here has been carried out within the Warsaw Metropolitan Area (WMA), within the limits set by "The Warsaw Metropolitan Area Development Study Plan" (Studium planu zagospodarowania przestrzennego obszaru metropolitalnego Warszawy)

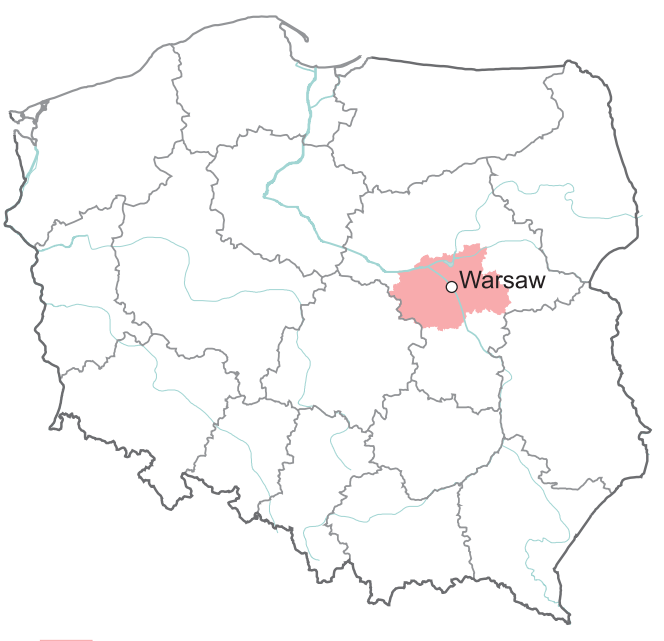

WMA (Warsaw Metropolitan Area)

Figure 1. The location of the study area (the WMA) as set against the (NUTS2) administrative division of Poland into voivodships. 
of 2010 (MBPR 2010). In the view of Komornicki and Śleszyński (2009), Warsaw's suburban zone stands out in Poland as a whole for being one of two large and compact zones of this kind displaying urban features (the second such area being the Upper Silesian/Cracow zone). The work by the authors referred to shows that conditioning favouring the development of the urbanisation process in Warsaw's outer suburban space, as opposed to in other suburban areas in Poland, includes a high intensity of inward migration, the development of entrepreneurship (most especially as regards higher-order services) and a large number of dwellings being given over for use.

Most of the work addressed here has been carried out within the framework of the research project now being implemented under the title "The ecological-landscape dimension to the urbanisation of rural parts of the Warsaw Metropolitan Area" (Ekologiczno-krajobrazowy wymiar urbanizacji terenów wiejskich Obszaru Metropolitalnego Warszawy), as well as project no. 2011/01/B/ HS4/06247, with funding from the National Science Centre (Narodowe Centrum Nauki). Comparisons were made using results from the research project "Development Trends of the Mazovia Region" (Trendy rozwojowe Mazowsza), as implemented in the years 2010-2011, having been commissioned by the Bureau of Regional Planning in Warsaw; as well as project no. 3PO4E04922 entitled "Changes in the landscape of the Warsaw Metropolitan Area in the late 20 and early 21 st centuries" (Zmiany krajobrazu Obszaru Metropolitalnego Warszawy na przełomie XX i XXI wieku), which was implemented in the years 2005-2007, with the financial support of Poland's State Committee for Scientific Research (Komitet Badań Naukowych).

\section{Assumptions, objectives and methods}

Undertaken research was directed at recognizing the process of urban growth in terms of spatial growth of urbanized land, with the special stress put on rural areas (rural gminas) of the Warsaw Metropolitan Area.

Year 2004 is considered to be a real turning point, since on May 1st Poland became a fullyfledged Member State of the European Union. Hence, the study embraced changes in the level of urbanisation in two time frames: from January
2000 to January 1st 2004, which constitute the pre-accession period, and the membership period, which alongside with first 4 months before the accession, began on January 1st 2004 to January 1st 2010. Particular stress was put on changes that had been taking place since 2004.

The three main hypotheses being advanced were:

- that distance from Warsaw ought to be a key influence on spatial urbanisation, especially in rural areas - whose distance from the capital might be expected to correlate inversely with the share of land that is urbanised, and most especially urbanised from the residential and housing-related point of view;

- that the years 2004-2010 witnessed a continuation of earlier trends where the geographical directions to intensive spatial urbanisation were concerned;

- that Poland's EU accession was associated with accelerated growth in the area of urbanised land within zones distinguished at different distances from Warsaw.

In line with the above, main objectives of the carried out studies were as follows:

- the recognition of the differentiation in the urbanization level of the WMA at the end of 2010 , based on the general index of the spatial urbanization, as well as on the index of residential urbanisation;

- the recognition of the regularities of the urbanised land development in the first decade of the 21 st century, along with the influence of distance from the centre of Warsaw on occurring changes.

Research into the spatial urbanisation of the Warsaw Metropolitan Area made use of statistical data from the Office of the Marshal of Mazowieckie Voivodship under the title "A collective compilation of land and building registrations" (Zestawienia zbiorcze ewidencji gruntów i budynków) as of the first day of January in the years 2000, 2004 and 2010, this being part of the resource of the Office of the Chief Surveyor of Mazowieckie Voivodship and the Office of the Marshall. The databases serving the needs of this study were founded on the basis of source data concerning areas of urbanised and residential land, as well as built-up rural areas, or else forest land and agricultural land. The completed data basis provided characterisations of land, that was referred to the unit of local government administration 
in Poland known as the gmina (municipality), and to the five categories of area: rural gminas (which include rural unit within urban-rural gminas and rural gimans), towns and cities, towns and cities other than Warsaw, Warsaw, and the WMA as a whole, as well as 5 zones of rural areas designated by reference to distance from Warsaw, with zone I extending out to a distance of $20 \mathrm{~km}$, zone II from 20-30 km, zone III from 30-40 km, zone IV from 40-50 km, and zone $V$ in excess of $50 \mathrm{~km}$. In assigning a gmina to a given zone, the variable of importance was the road distance travelled from the centre of Warsaw to the actual seat of the given local authority.

The database described served in the devising of cartograms, cartodiagrams, regression models and regression lines, all used in determining spatial regularities to the development of urbanised land. A description of adopted criteria relating to similarities in the changes affecting urbanised land (and with trends as regards agricultural and forest land also accounted for) has been included in Chapter 4.2. To assess the way in which distance from central Warsaw influences the urbanisation of rural areas, analyses were performed for the relationship between distance and values for an index of the spatial urbanisation of rural gminas (i.e. the share of the land in the gmina that is urbanised) and their residential urbanisation (in terms of the share of all land in the gmina accounted for by residential construction), as well as absolute changes in the areas accounted for by these categories of land. Regression modelling of the relationships obtained was carried out using the CurveExpert Professional 1.6 program, while graphical development of maps was engaged in by A. Deręgowska, using the program Maplnfo Professional 10.5.

\section{The level of WMA urbanisation in $\mathbf{2 0 1 0}$}

Despite the very intense urbanisation that has recently been taking place and its effects, which influence i.a. the landscape and the land use, the share of urbanised land within the Warsaw Metropolitan Area (excluding Warsaw) still accounts for $11 \%$ with built-up urban areas amounting to as little as $6.5 \%$. In contrast, the share accounted for by farmland remains high in all parts (Fig. 2), even in the external zone of Warsaw itself, and several towns within the WMA. In the case of the capital, this reflects the regular inclusion within its limits of further agricultural areas, the expansion outpacing the actual need for further residential construction. In turn, up until the time of Poland's socioeconomic transformation, Warsaw's suburban zone was the main source of food for the city, ensuring the presence there of the very high values for the share of land devoted to agriculture obtained in the work by Zgliński (1994).

There is still clear difference between the highly-urbanised core and the outer zone, within the WMA (Fig. 3). In terms of the value of the spatial urbanisation index, Warsaw is ranked on the 10 place. Urbanised land prevails in cities: Pia-

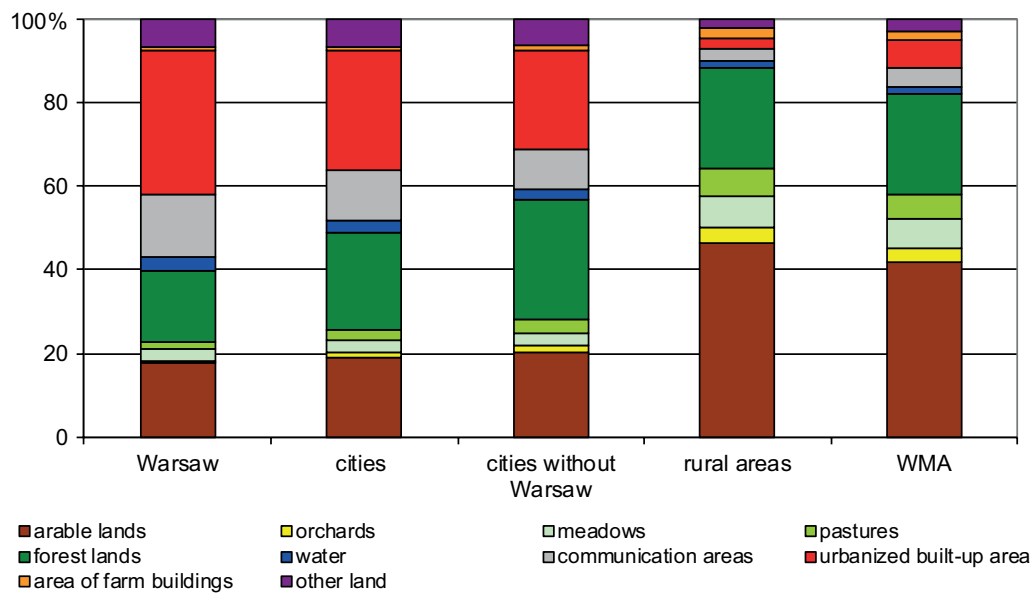

Figure 2. Share of urbanised land and other forms of land cover in different categories of area in the end of 2010. 
stów (86\%), Legionowo (77\%), Łomianki (71\%), Grodzisk Mazowiecki (70\%), Mińsk Mazowiecki (68\%), Żyrardów (65\%), Piaseczno (64\%), Pruszków (63\%), Halinów (56\%), Milanówek (55\%), Warsaw (54\%) and Brwinów (50\%). Where the value for the index of spatial urbanisation is concerned, Warsaw takes 10th place. Urbanised land prevails in the towns of Piastów (86\%), Legionowo (77\%), Łomianki (71\%), Grodzisk Mazowiecki (70\%), Mińsk Mazowiecki (68\%), Żyrardów (65\%), Piaseczno (64\%), Pruszków (63\%), Halinów (56\%), Milanówek (55\%), Warsaw (54\%) and Brwinów (50\%).

Rural areas are characterized by the low rate of urbanisation (5.8\%), with the inner zone around
Warsaw reporting somewhat higher value and the most of gminas of outer zone recording extremely low (Fig. 3). Among the rural units (gminas) the following ones stood out: Michałowice (25\%) and Raszyn (18\%), as they recorded in 2010 higher rate than several cities of the WMA, mainly Zakroczym (9\%), Zielonka (9\%), Kałuszyn (11\%), Karczew (14\%) and Serock (17\%).

The differentiation noted for gminas in relation to residential urbanisation reflects the spatial breakdown for urbanised land. The towns in which the share of residential land is higher than in Warsaw include: Piastów (49\%), Legionowo (47), Łomianki (47\%), Milanówek (36), Piaseczno (30\%),

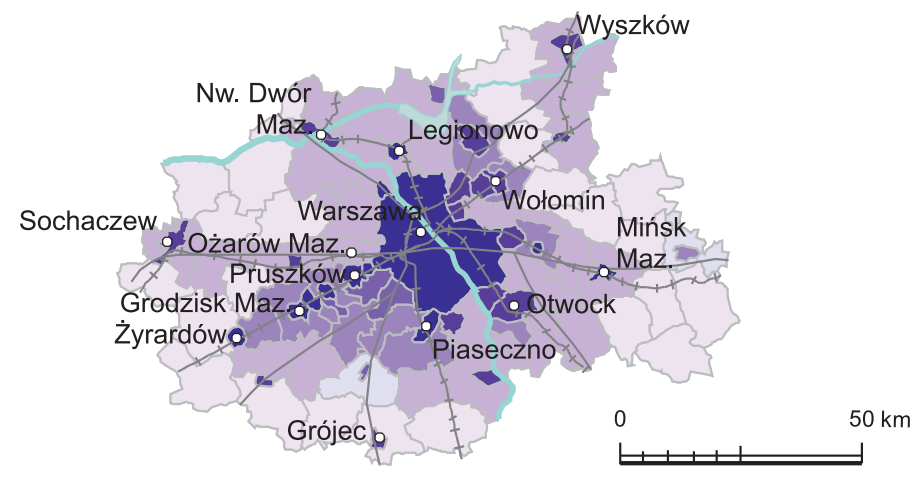

$\begin{array}{lllll}0 & 510 & 15 & 25 & 50\end{array}$

Figure 3. Differences between the gminas of the WMA from the point of view of the index of spatial urbanisation in 2010 .

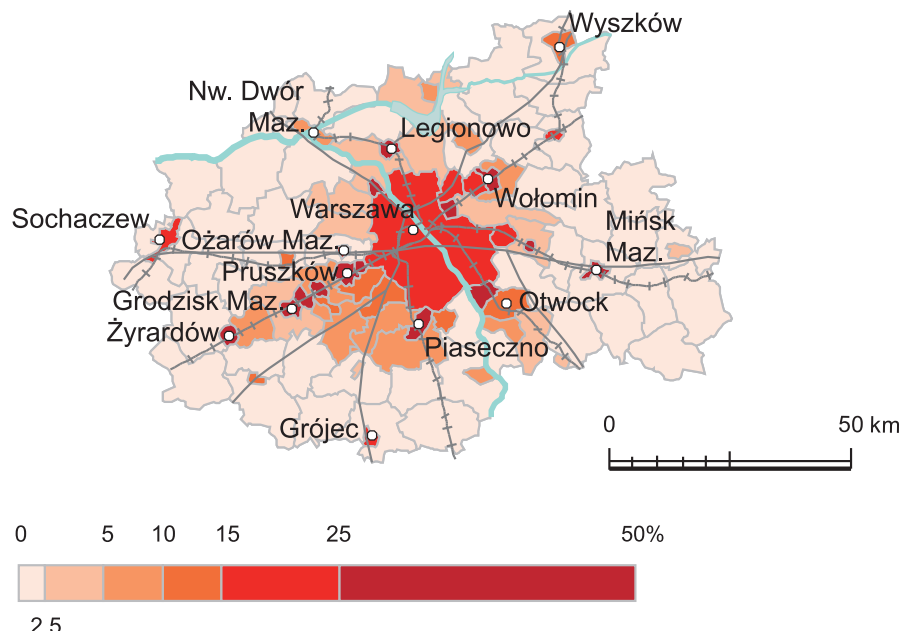

Figure 4. Differences between the gminas of the WMA from the point of view of the index of residential urbanisation. 
Halinów (34\%), Brwinów (33\%) Grodzisk Mazowiecki (31\%), Mińsk Mazowiecki (30\%), Ząbi (28\%), Pruszków (26\%), Żyrardów (25\%), Józefów (25\%), Sulejówek (24\%), Kobyłka (23\%), Tłuszcz (21\%) and Marki (19\%). Within the network of urban areas within the WMA, Warsaw takes only 18th place with $18 \%$ of its land accounted for by residential areas.

Rural areas are characterised by relatively low values for the shares of land featuring residential construction (Fig. 2). In half of the rural areas of the WMA, residential land accounts for less than $1 \%$ of the total. These are areas located beyond the limits of the old voivodship of Warsaw, forming a broad external zone of space urbanised to only a very limited extent (Fig. 4).

In the case of only two of the gminas in rural areas does the value for the index reach or exceed $10 \%$ (with 14\% noted in the case of Michałowice and $10 \%$ for Raszyn). There are then a further 5 with values in the range 5-7\% (i.e. Jaktorów, Lesznowola, Piaseczno, Nadarzyn and Wołomin). Most of the rural units with relatively higher values for the index of residential urbanisation are close to Warsaw or constitute a rural area in an urban-rural gmina. Unlike in 2000 (when no distinct increase in the value for this index was to be noted in the vicinity of lower-order urban centres (Degórska \& Deregowska 2008)), the late 2010 data found an elevated level of residential urbanisation in their vicinity. Beyond that, in relation to the year 2000 there had been a marked increase in the level of residential urbanisation in all rural gminas.

\section{Typology of gminas in terms of urban growth}

To identify gminas displaying similar regularities where the changes in areas of urban, agricultural and forest land are concerned, a typology was devised in line with the criteria presented in Table 1. In this context it should be noted at the outset that the attempt to use cluster analysis to identify, and distinguish between, types of rural gmina displaying similar changes where the areas of the different land categories were concerned proved of limited value, on account of the skewed nature of the observed distribution of data.

The basic criterion adopted was the mean annual change in areas of urbanised land, with account taken of the trends for changes in forest and agricultural land (loss or gain). The second key criterion revolved around an attempt to identify gminas with relative stability as regards urbanised, forest and agricultural land, irrespective of directions to changes. In line with these adopted criteria, some five main types of gmina were identified (Fig. 5):

- type A - a major increase in urbanised areas (mean $>20$ ha/year);

- type B - a moderate increase in urbanised areas (mean $>5$ to 20 ha/year);

- type C - a slight increase in urbanised areas (mean up to $5 \mathrm{ha} /$ year), with the exception of units classified as type $\mathrm{E}$;

- type D - no change in or decrease only of urbanised areas, with the exception of units classified as type E;

- type E - small changes in the urbanised areas, forest land and arable land, on average up to 5 ha per year for each of them. The gminas encompassed by this type display relatively the greatest level of landscape stabilisation irrespective of directions to changes.

The determination of types $A, B$ and $C$ took as its leading criterion the mean increase in area of urbanised land in the analysed period, with the highest values characterising type $A$, intermediate values type $B$ and low values type $C$.

In types $A, B, C$ and $D$, the changes in the area of at least one of the two land categories (forest and/or agricultural) had to exceed 5 ha per year on average.

The sub-types for types A and B were distinguished in line with the trends for changes in forest and agricultural land (loss or gain).

The sub-types for type $C$ and $D$ were distinguished in line with the trends for forest land, with no consideration given to farm land, albeit excluding gminas assigned to type $E$.

Given that the WMA represents rather low level of forest cover, a particularly disquieting phenomenon refers to Types $A 1$ and $A 2$, in which growth of the area of urbanised land is accompanied by the decline in the forest area. Excluding the majority of gminas located within the WMA's external zone, the indicated direction to changes in the landscape takes in areas located mainly to the south, south-west and north of Warsaw, as well as the whole of the north-eastern belt. Almost all rural units with a relatively high share of urbanised land are characterised by further reductions in forest cover. 


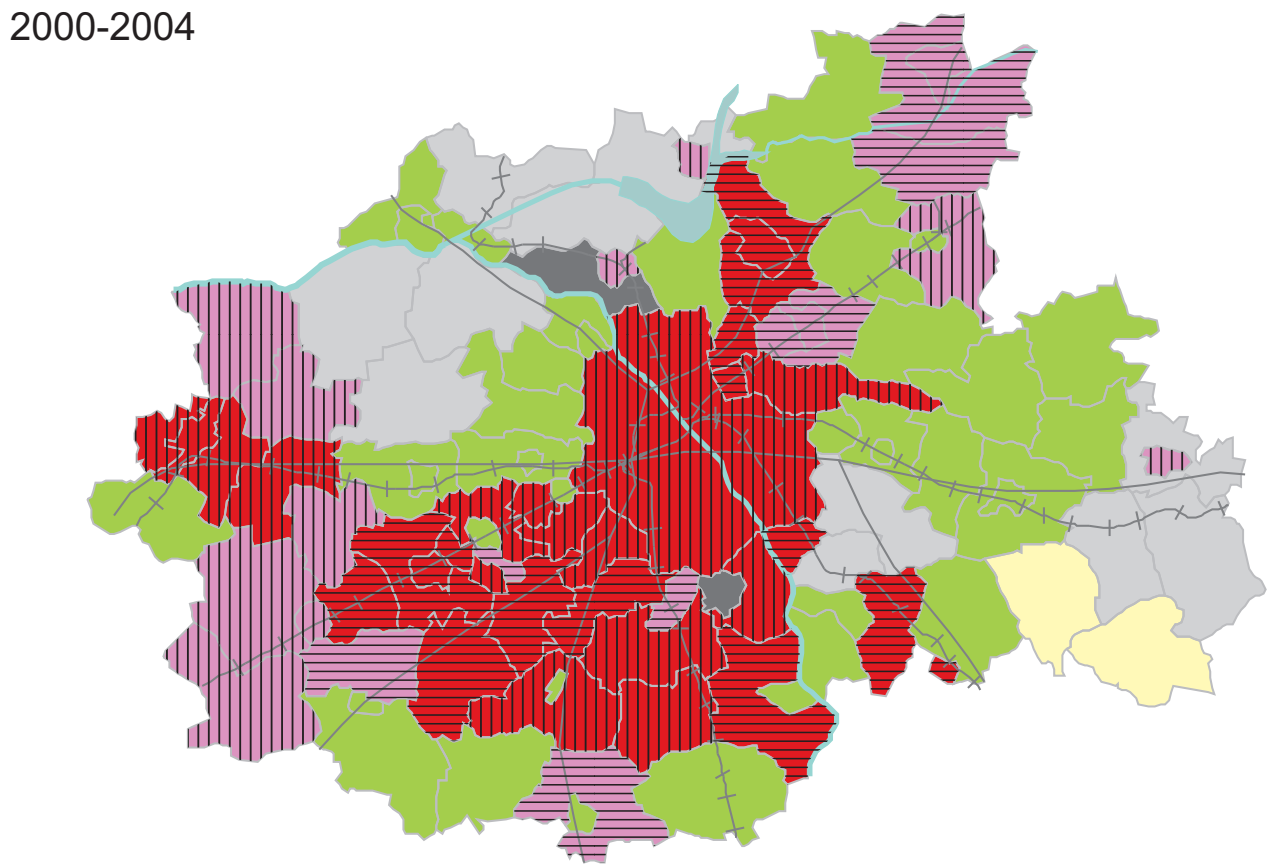

2004-2010

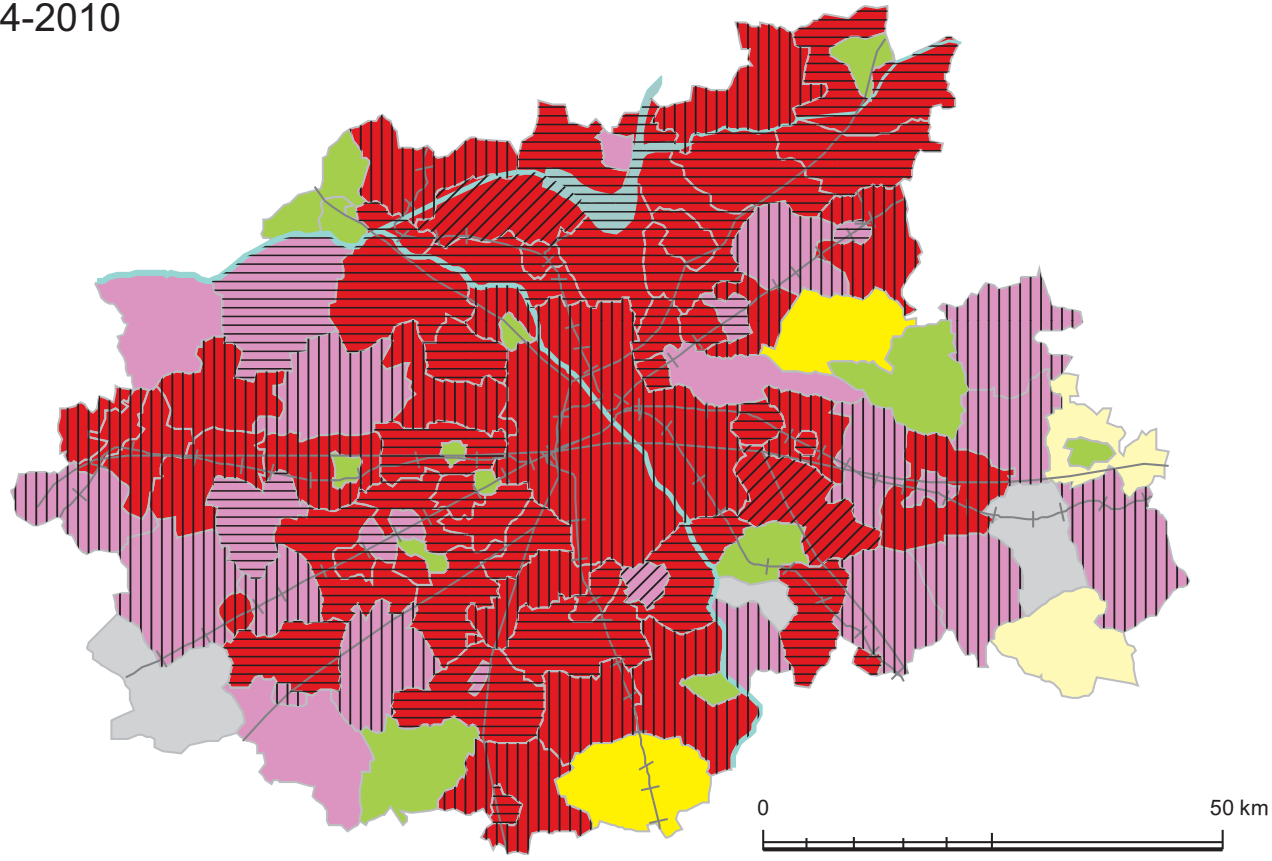

\begin{tabular}{|c|c|}
\hline A1 & 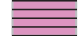 \\
\hline A2 & W/1/, \\
\hline A3 & $\|$ \\
\hline
\end{tabular}

Figure 5. Typology of gminas in terms of urban growth. 
Table 1. Criteria for the classification of rural gminas, taking account of changes in area of urbanised, forest and arable land.

\begin{tabular}{|c|c|c|c|c|}
\hline \multirow{2}{*}{ Type } & \multirow{2}{*}{ Subtype } & \multicolumn{3}{|c|}{ Nature of the changes } \\
\hline & & urbanised land & forest land & agricultural land \\
\hline A & $\begin{array}{l}\text { A1 } \\
\text { A2 } \\
\text { A3 }\end{array}$ & $\begin{array}{l}\text { average increase in area } \\
\quad>20 \text { ha /year } \\
\text { average increase in area } \\
>20 \text { ha /year } \\
\text { average increase in area } \\
\quad>20 \mathrm{ha} / \text { year }\end{array}$ & $\begin{array}{l}\text { decline in area } \\
\text { decline in area } \\
\text { increase in area }\end{array}$ & $\begin{array}{l}\text { decline in area } \\
\text { increase in area } \\
\text { decline in area }\end{array}$ \\
\hline B & $\begin{array}{l}\text { B1 } \\
\text { B2 } \\
\text { B3 } \\
\text { B4 }\end{array}$ & $\begin{array}{l}\text { average increase in area } \\
\text { from }>5 \text { to } 20 \text { ha/year } \\
\text { average increase in area } \\
\text { from }>5 \text { to } 20 \text { ha/year } \\
\text { average increase in area } \\
\text { from }>5 \text { to } 20 \text { ha/year } \\
\text { average increase in area } \\
\text { from }>5 \text { to } 20 \text { ha/year }\end{array}$ & $\begin{array}{l}\text { decline in area } \\
\text { decline in area } \\
\text { increase in area } \\
\text { increase in area }\end{array}$ & $\begin{array}{l}\text { decline in area } \\
\text { increase in area } \\
\text { decline in area } \\
\text { increase in area }\end{array}$ \\
\hline $\begin{array}{l}\mathrm{C} \text { (other than units } \\
\text { assigned to type } \mathrm{E} \text { ) }\end{array}$ & $\begin{array}{l}\mathrm{C} 1 \\
\mathrm{C} 2\end{array}$ & $\begin{array}{l}\text { average increase in area } \\
\text { of up to } 5 \mathrm{ha} / \text { year } \\
\text { average increase in area } \\
\text { of up to } 5 \mathrm{ha} / \text { year }\end{array}$ & $\begin{array}{l}\text { decline in area } \\
\text { increase in area }\end{array}$ & $\begin{array}{l}\text { increase or decline in area } \\
\text { increase or decline in area }\end{array}$ \\
\hline $\begin{array}{l}\text { D (other than units } \\
\text { assigned to type } E \text { ) }\end{array}$ & $\begin{array}{l}\text { D1 } \\
\text { D2 }\end{array}$ & $\begin{array}{l}\text { no change or loss } \\
\text { no change or loss }\end{array}$ & $\begin{array}{l}\text { decline in area } \\
\text { increase in area }\end{array}$ & $\begin{array}{l}\text { increase or decline in area } \\
\text { increase or decline in area }\end{array}$ \\
\hline$E$ & - & $\begin{array}{c}\text { average increase or decline in } \\
\text { area of up to around } \\
5 \text { ha/year }\end{array}$ & $\begin{array}{c}\text { average increase or decline in } \\
\text { area of up to around } \\
5 \mathrm{ha} / \text { year }\end{array}$ & $\begin{array}{c}\text { average increase or decline } \\
\text { in area of up to around } \\
5 \mathrm{ha} / \text { year }\end{array}$ \\
\hline
\end{tabular}

An increase in forest cover with simultaneous development of urbanised areas is a characteristic feature for the urbanised core of the WMA, as well as the still weakly-urbanised external zone.

\section{Impact of distance from the centre of Warsaw on the urban growth}

While the first half of the studied period was associated with ongoing urbanisation of rural space in all zones, the most major changes were nevertheless those encompassing zone $1(<20 \mathrm{~km})$, while those elsewhere were far more limited in extent Figure 6. Moreover, a markedly higher value of the index of spatial urbanisation characterised zone I, while gminas of zones II, III and IV (at distances of 20 to over $50 \mathrm{~km}$ ) all presented rather similar, lower values.

Following Poland's accession to EU structures, the process of spatial urbanisation was very much enlivened in all zones (Fig. 6). Nevertheless, it was again in zone $\mathrm{I}(<20 \mathrm{~km})$ alone that values for the index exceeded 10\%. Along with increasing distance from Warsaw, the values declined quite steadily, the relationship being best described by geometric models (Fig. 7).

The correlation coefficient assumed a much higher value $(r=0.700)$ in the case of 2010 , as opposed to 2004 ( $r=0.554$ ), suggesting a strengthening of the relationship between spatial urbanisation and distance from Warsaw (Fig. 7). It needs to be noted that the influence of distance is more distinctive nearer to Warsaw, while rural gminas

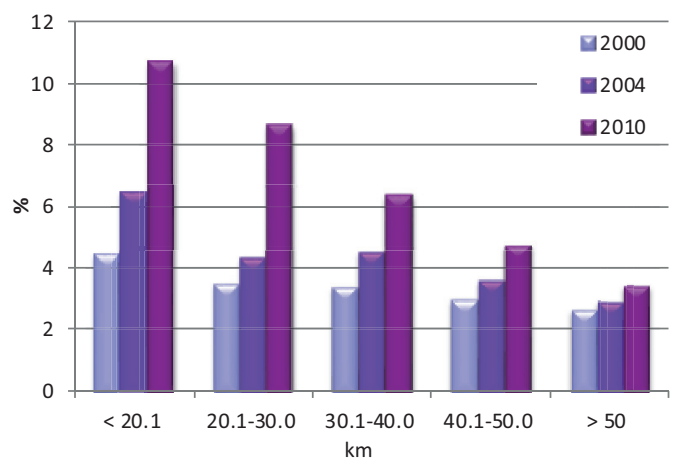

Figure 6. Share of urbanised land in the rural gminas in terms of distances from the center of Warsaw. 


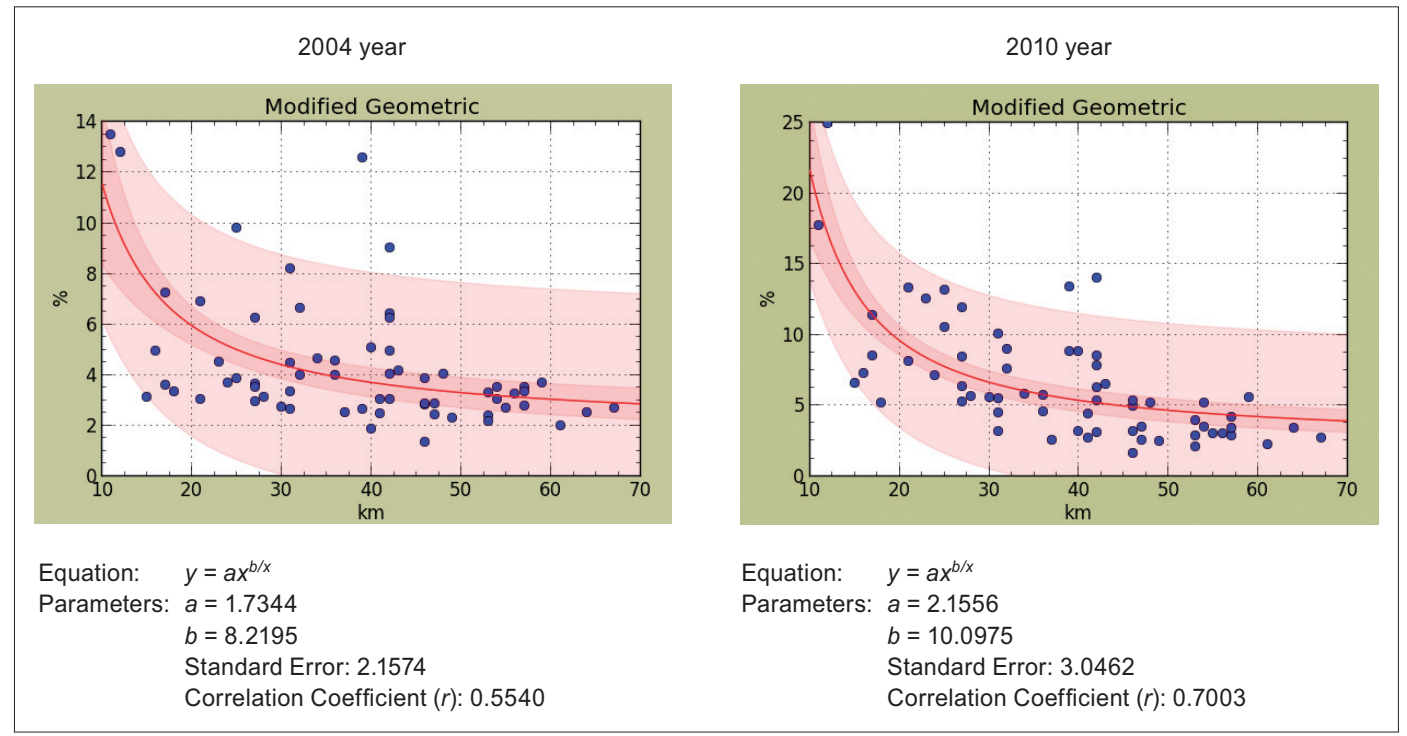

Figure 7. Relationship between distance from the centre of Warsaw $(x)$ and the share of urbanised land in the rural gminas (y).

around $40 \mathrm{~km}$ from the centre are influenced to only a very limited extent.

Comparison of spatial differences as regards the dynamic for area of urbanised land, the absolute change in area and the rates of these changes in the periods 2004-2010 and 2000-2004 (Degórska \& Deręgowska 2008, Fig. 8) revealed a major post-2004 shift in the main geographical directions to spatial urbanisation. While the 2000-2004 period had mainly brought more dynamic growth in the area of urbanised land to the south and west of Warsaw, as well as in several gminas to the south-west (Degórska \& Deręgowska 2008), in the years 2004-2010 it was mainly areas to the north, east and north-west of Warsaw that were involved, and in connection with a far more dynamic trend (Fig. 8). The reported new directions characterised by intensive changes in areas of urbanised land are associated with absolute changes in the area accounted for by this kind of

\section{$2004=100 \%$}

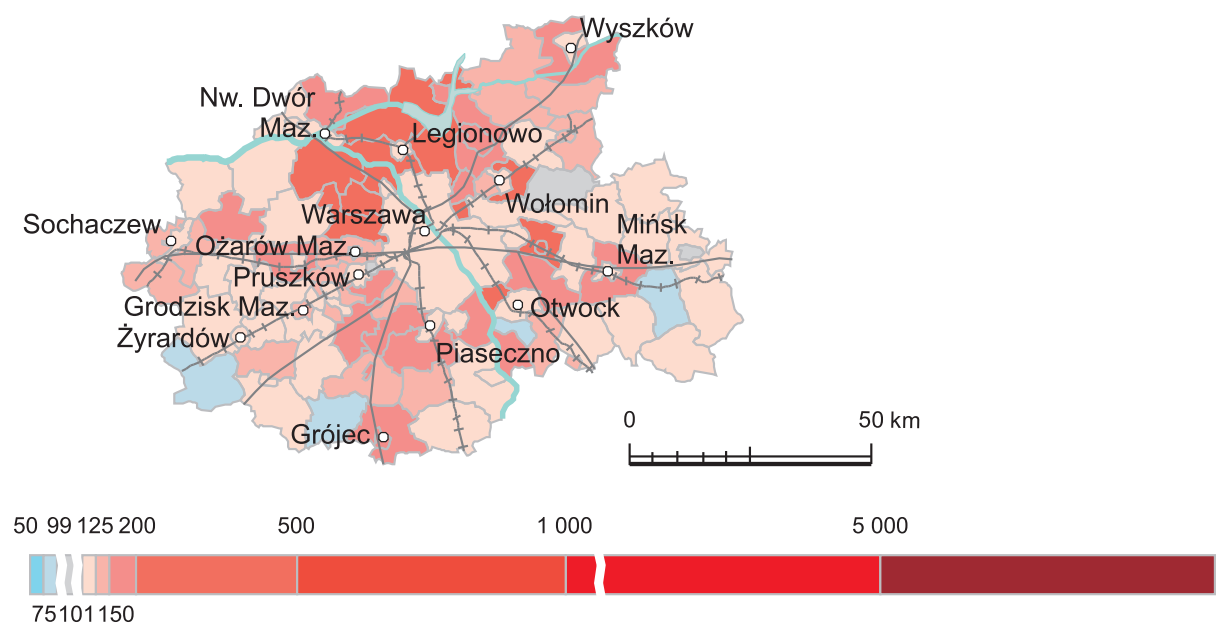

Figure 8. Spatial differentiation of dynamic of the urbanised land over the period 2004-2010 (in \%). 
land. The largest increases in the period affected the northerly direction (Fig. 9), rather than areas to the south and west of Warsaw that had been involved in the previous period.

The dynamic to changes in area and the absolute changes in area thus point to the manifesting of new geographical directions to growth in the area of urbanised land, though they do not define the comparable rate of these changes in connection with periods of different length.

The rate of increase in the area of urbanised land in rural gminas has been determined for zones at different distances from the centre of Warsaw, in terms of the mean growth in area in the given period as calculated per year. This analysis shows that the urbanisation of rural areas has progressed far more intensively post-2004 than in the previous period. While the years 2000-2004 brought highintensity growth in the urbanised areas characteristic of the zones 30-40 and 40-50 km out from the centre of Warsaw, it was above all the zones at distances of $20-30 \mathrm{~km}$ that was affected in the 2004-2010 period, the mean rate of development of urbanised land here tripling (Fig. 10).

It emerged that the so-called 'Rational Model' was the statistical model best describing the rela-
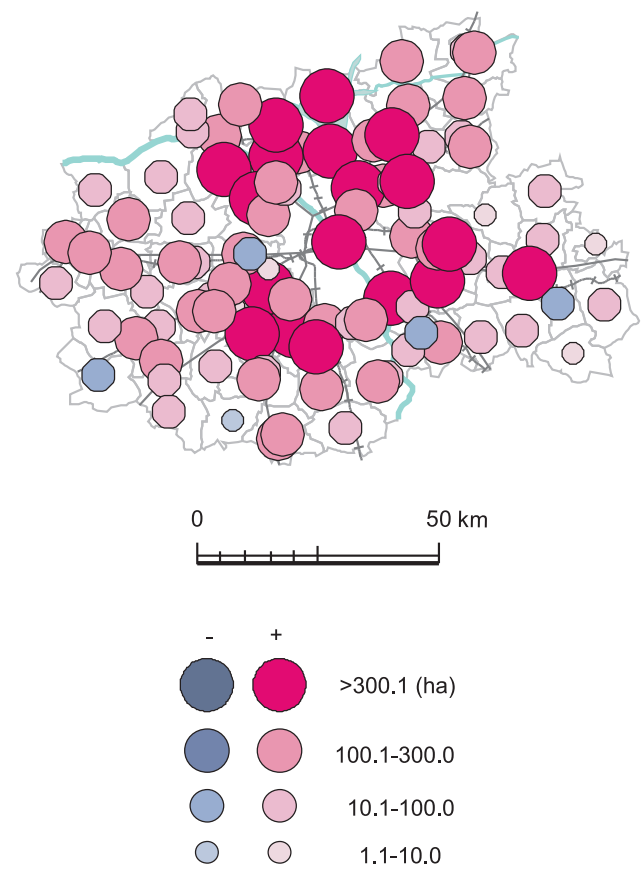

Figure 9. Spatial differentiation of changes of the urbanised land over the period 2004-2010 (in hectares). tionship between distance from the centre of Warsaw by road and differences in the area of land that was urbanised across the period 2004-2010. Analysis of the regression curve shows that, in the years in question, the area of new land encompassed by the urbanisation process was greater at greater distances from the centre, attaining maximum values some $20-25 \mathrm{~km}$ out, and then being maintained at a rather similar level to as far away as some $45 \mathrm{~km}$ (Fig. 11).

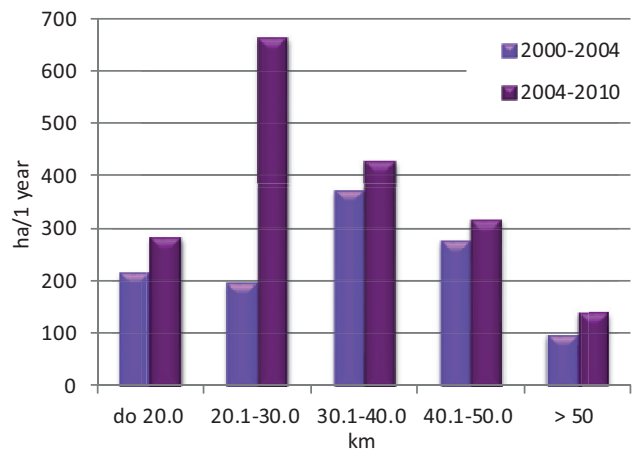

Figure 10. Average rate of growth in the area of urbanised land within the rural gminas (in ha per year) in terms of distance from the centre of Warsaw.

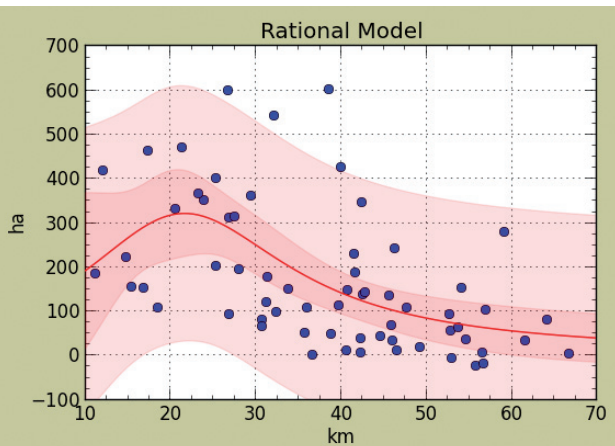

Equation: $\quad y=\frac{a+b x}{1+c x+d x^{2}}$

Parameters: $a=89.2568$

$b=1.0963$

$c=0.0635$

$d=0.0015$

Standard Error: 135.9168

Correlation Coefficient (r): 0.5572

Figure 11. Relationship between distance from the centre of Warsaw $(x)$ and changes in the area of urbanised land in rural gminas over the period 2004$2010(y)$. 
The course of the regression curve also indicates that, at distances in excess of $40 \mathrm{~km}$ from central Warsaw, the marked influence of distance on changes in the share of land that is urbanised becomes very much curtailed.

\section{Impact of distance from the centre of Warsaw on growth of residential areas}

The most transformations of rural landscape into urban landscape within the WMA were triggered by the urban sprawl, mainly by erection of new residential buildings. The transformations involved relate to trends characterising urbanised land. At the beginning of the decade under analysis - in 2000 - it was only in the gminas located closest to Warsaw that the shares of land serving a residential function were relatively high. Other gminas were characterised by very low and rather similar shares of residential land (Fig. 12). By 2004, the picture is more differentiated, with a clear dominance in the first zone, and a lowering to a similar level in zones II (at 20-30 km) and III (30-40 km), plus a further lowering to around $1 \%$ in the zone most distant from Warsaw. A marked increase in the level of residential urbanisation in all zones took place over the period 2004-2010, with almost a doubling in zones I, III and IV, and around a trebling in zones II and V. A characteristic feature for the last of the years is a rather evenly declining share of residential land in successive zones characterised by increasing distance from Warsaw.

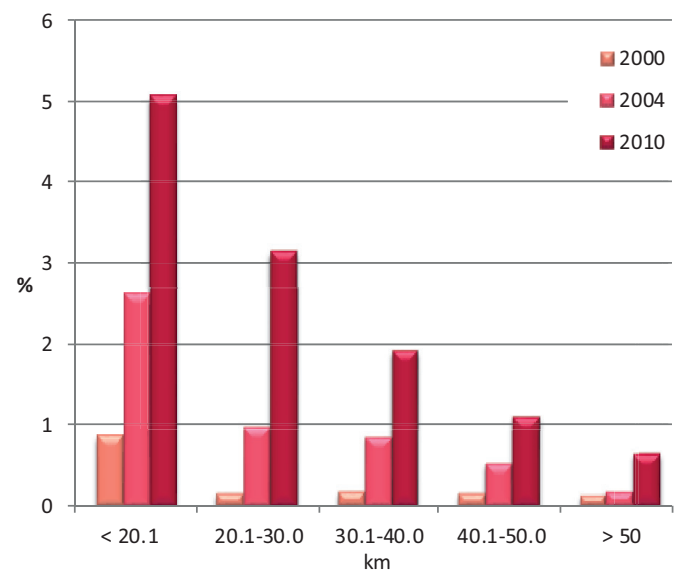

Figure 12. Share of residential areas in the rural gminas in terms of distance from the centre of Warsaw.
The ever-stronger relationship between the residential urbanisation of rural areas and distance from Warsaw is confirmed by correlation analysis carried out for successive years. While the correlation coefficient assumed a value of 0.628 in 2004, the corresponding figure for the last year of the study was 0.729 (Fig. 13). It is possible to note a stronger link between residential areas and the distance from the centre of Warsaw than applied in the case of the share of urbanised land.

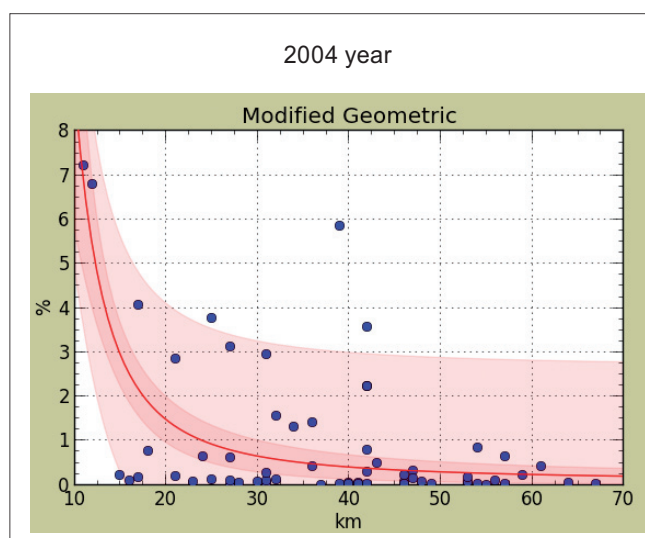

Equation: $\quad y=a x^{b / x}$

Parameters: $a=0.0520$

$b=22.3380$

Standard Error: 1.2891

Correlation Coefficient $(r): 0.6277$

2010 year

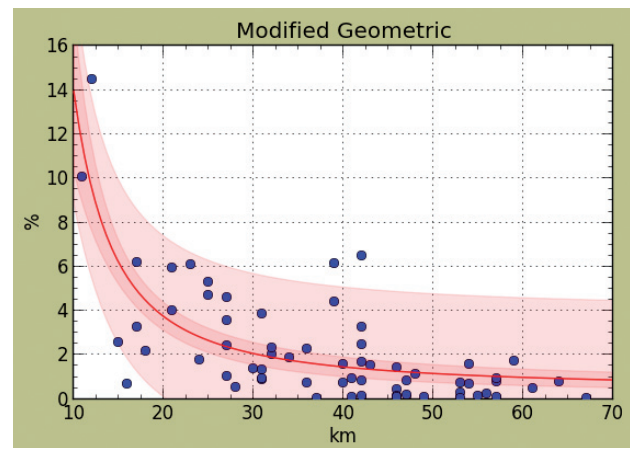

Equation: $\quad y=a x^{b / x}$

Parameters: $a=0.3224$

$b=16.3353$

Standard Error: 1.7954

Correlation Coefficient (r): 0.0.7287

Figure 13. Relationship between distance from the centre of Warsaw $(x)$ and the share of residential areas in the rural gminas $(y)$. 
In the years 2004-2010, the greatest dynamic for the increase in extent of residential areas was to be noted to the east of Warsaw, mainly in Mińsk Mazowiecki and its environs, as well as to the north of the capital, most especially in the gminas located along the Rivers Bug and Narew (Fig. 14). In contrast, in the same period, areas east of Warsaw also manifested the lowest dynamic for growth in residential urbanisation, a high dynamic mostly being typical for areas to the south, southwest and west of Warsaw, as well as to the north of the city to a more limited degree (Degórska \& Deregowska 2008).

Also reported was the emergence of new areas in which the greatest absolute changes in the area of residential land had taken place. While a zone located to the south and south-west of Warsaw dominated where the processes in question were concerned in the 2000-2004 period (Degórska \& Deręgowska 2008), thereafter that area lost its dominant position to the northern belt (Fig. 15). In rural areas the greatest changes to be noted were those in two units of the northern belt, which is to say in the gmina of Nieporęt (where the area of land of this kind increased by $333 \mathrm{ha}$ ), as well as in the rural part of the gmina of Serock (where the increase entailed a 424 ha area).

The analysis of the rate of change in the area of residential land (Fig. 16) shows that it was only in the zone immediately adjacent to the city that the rate was higher in the years to 2004 than in the subsequent period to 2010. Elsewhere the rate of change was greater in the 2004-2010 period - much greater in zones II (at 20-30 km) and V $(>50 \mathrm{~km})$, and rather greater in zones III $(30-40 \mathrm{~km})$
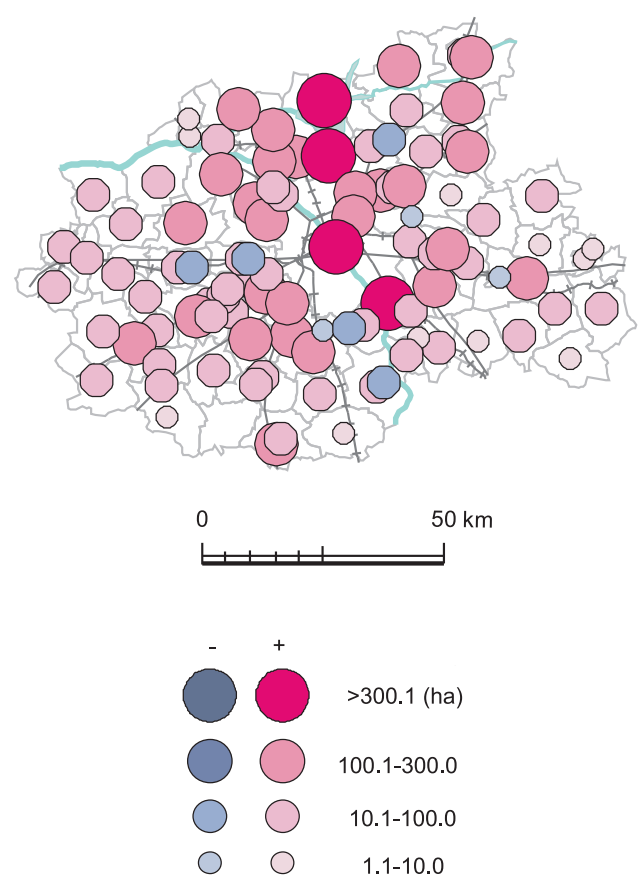

Figure 15. Spatial differentiation of changes of residential areas over the period 2004-2010 (in hectares).

$2004=100 \%$

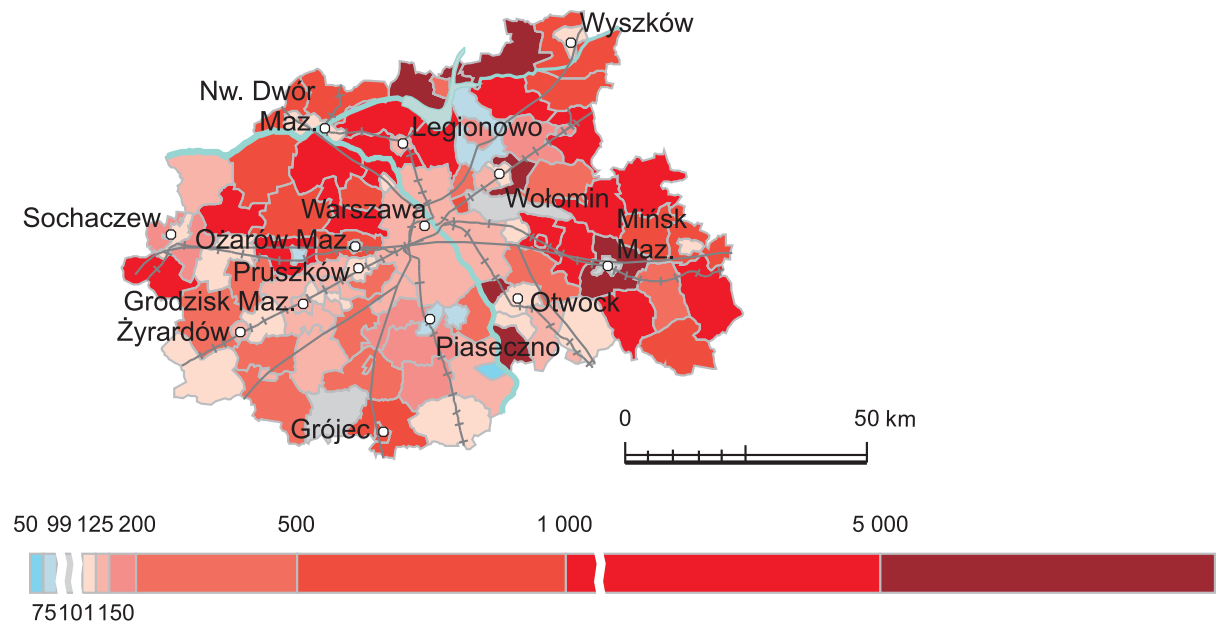

Figure 14. Spatial differentiation of the dynamics of the residential areas over the period 2004-2010 (in \%). 
and IV (40-50 km). In the first period, the rate of change rose in the first three zones, while in the second it only rose in two, before being subject to a lowering with increasing distance.

The relationship between distance from Warsaw and changes in the area of residential land over the 2000-2010 period is well illustrated by the 'Rational Model' (Fig. 17). This analysis confirmed the presence of a statistically significant relationship ( $r=0.581$ ), though the association is admittedly not a very strong one. As with the urbanised land, the course taken by this regression curve indicates that ever-greater distances from the centre of Warsaw are at first associated with an increase in the amount of new land coming under housing construction. This continues out to a distance of around $25 \mathrm{~km}$, before a marked downward trend takes hold, to the point where the relationship has become very weak by the time distances greater than $40-45 \mathrm{~km}$ are reached.

In turn, however, there was no statistically significant relationship to be noted between distance from the centre of Warsaw and the ratio of newly-residential areas of land built up in the years 2004-2010 to the area of newly-urbanised land. This points to the relationship being a very complex one.

The development of housing construction ensured that rural areas of the WMA experienced rapid changes in the relationship between the share of land with residential housing construction and the share with construction associated with agriculture (i.e. farm buildings) - Figure 18.

In 2000, rural areas in all zones displayed a marked dominance of land with buildings associated with inhabitants' agricultural activity (Fig. 18). However, the period under study has brought an increase in the share accounted for by residential construction, to the point where the latter has come to dominate over construction associated with farming. Up to 2004, notwithstanding a considerable increase in the share of land with either farm or residential buildings accounted for by the latter, there was still no zone in which it had come to prevail. The most stable situation was that characterising the zone more than $50 \mathrm{~km}$ out from the centre of Warsaw. The subsequent (2004-2010) period may be termed a breakthrough where the residential urbanisation of the WMA's rural areas was concerned, since the two zones up to $30 \mathrm{~km}$ distant from the centre witnessed the area under residential construction come to prevail over the area with farm buildings, while the next zone out was characterised by similar shares of each kind. In turn, in the zone more than $40 \mathrm{~km}$ away from central Warsaw the share of residential construction did increase, but not to a level at which it any way rivalled the area with farm-related construction. In 2010, the situation as regards the shares of the different kinds of built-up area in the zone $50 \mathrm{~km}$ from Warsaw resembled that

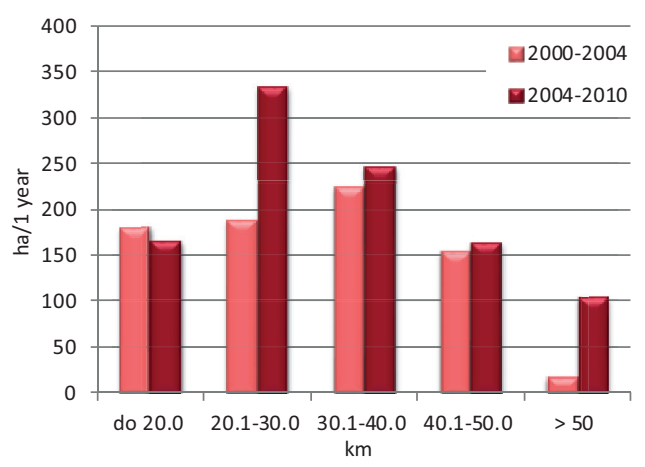

Figure 16. Average rate of growth in the area of residential land within the rural gminas (in ha per year) in terms of distance from the centre of Warsaw.

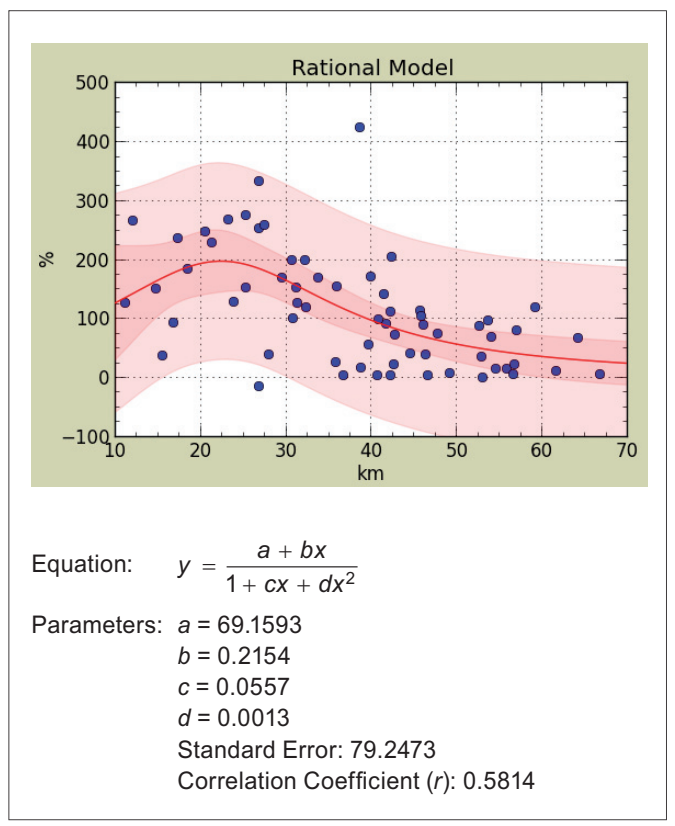

Figure 17. Relationship between distance from the centre of Warsaw $(x)$ and changes in the area of residential areas in rural gminas over the period 2004-2010 (y). 

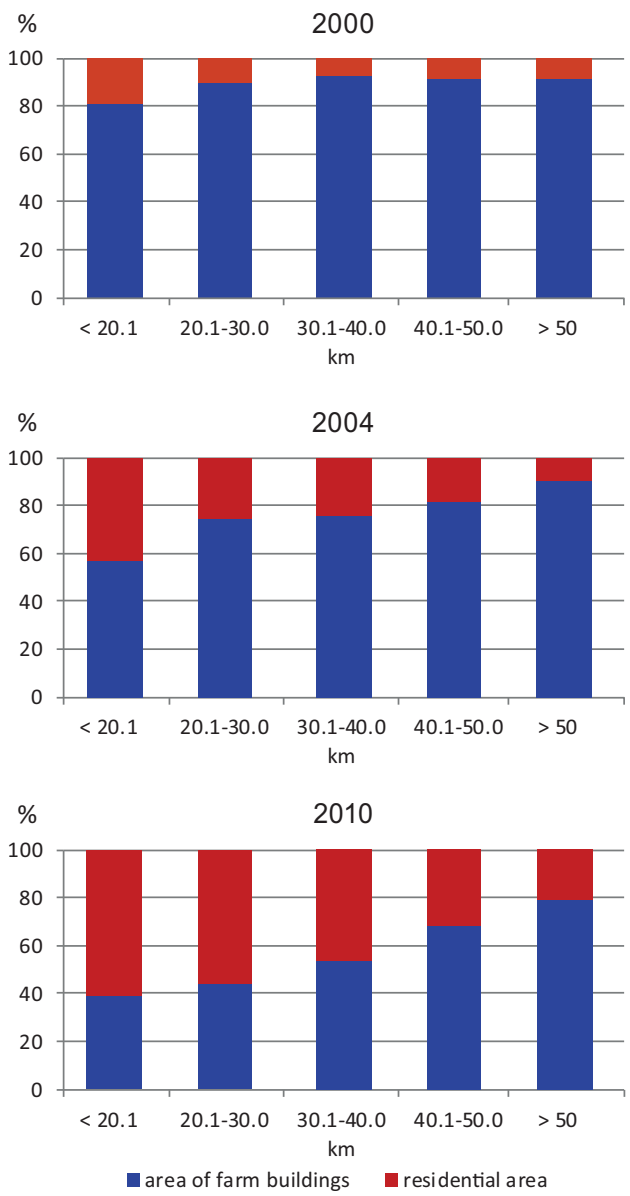

Figure 18. Relationship between the shares of households areas (land with farm buildings) and residential areas, with regard to the rural areas as well as to the distance from the centre of Warsaw.

characterising zone I ( $<20 \mathrm{~km}$ away) at the beginning of the study period, this attesting to very intensive transformations ongoing in the rural parts of the WMA.

\section{Discussion and summary}

The present spatial configuration of urbanised (including also residential) land within the Warsaw Metropolitan Area mainly links up with the historical development of that area's settlement network, and with the layout of its transport system. In the environs of Warsaw, the highest values for the indices of spatial urbanisation and residential urbanisation characterise a belt running along the main road and rail routes into Warsaw. In the post-War period, various towns grew in population in line with the considerable restrictions on registering as a resident that applied in Warsaw proper for a rather long period through until the 1970s. The towns of the then 'capital city voivodship' were thus the main places inhabited by people from beyond Warsaw who nevertheless worked in the capital in its main industrial plants, alongside further residents employed in the industry operating in those satellite towns themselves (Śleszyński 2012).

In contrast, the rural areas of the WMA continue overall to be characterised by a rather limited degree of both spatial and residential urbanisation, though rather higher levels are noted in an interior zone mainly encompassing gminas (local authority areas) bordering directly on to Warsaw, or else located to the south-west of it. Values are in turn very low in most of the gminas forming the outer zone (Fig. 3), and most especially in those located beyond the limits of the old Warsaw voivodship.

Research has thus confirmed the existence of a statistically-significant relationship between distance from Warsaw and level of spatial and residential urbanisation. Nevertheless, at distances around $40-45 \mathrm{~km}$ from the city centre, this relationship becomes very much attenuated. Equally, the passage of time is shown to have been associated with an ever-greater influence exerted by distance on the level of urbanisation.

The study presented here likewise points to an ever-more intensive process by which rural areas of the WMA are made over into space of an urban character. However, this in no way means that the share of land accounted for by agriculture is in more major decline, this reflecting the role of Warsaw's suburbs as important sources of food for the capital itself - today, just as they were when reported on by Zgliński (1994). While the period of transformation did indeed see farming activity cease in quite a large number of areas, land left fallow in one way or another often retains an agricultural designation from both the actual and formal points of view, hence an ongoing major role in the land-use structure of the WMA (Fig. 2).

Processes of suburbanisation, above all urban sprawl, are changing the landscape as buildings and built-up areas remain scattered across space, but area also distributed ever more widely overall. The most profound changes of this kind characterise rural areas - a fact that is best attested to by the change in the relationship between the shares of the total area accounted for by land with residential 
construction or else land with the so-called zabudowa siedliskowa (an official category denoting construction either residential or non-residential, but intimately associated with the activity of farming). In the two first zones, building of the former kind now prevails over the latter, while even further out, there has been a marked development of construction not connected directly with farming (Fig. 18).

The development of urbanised (including residential) land is favoured by a spatial policy on the part of many gminas provided for in their "studies of the conditioning and directions to physical development" provided for in law. Strzelecki and Holcel (2008) show that rural areas of the WMA have global reserves of land designated for building of some 134,000 ha, representing a potential level of development $70 \%$ beyond the existing situation. The potential growth in residential land would, according to Strzelecki and Kucińska (2006), suffice to meet the needs of an agglomeration of 7-8 million people. Thus, bearing in mind the demographic trends in place for several years now (Śleszyński 2012), it is reasonable to suggest that the gminas' intentions where the development of residential areas is concerned go far beyond the real need for new housing.

Among the main factors favouring the development of urbanisation in the WMA - other than a spatial policy at gmina level posited on the development of residential land and other areas of economic activation (Strzelecki \& Holcel 2008) - are the development of entrepreneurship, a high intensity of inward migration and a relatively large number of dwellings given over for use (Komornicki \& Śleszyński 2009). Suburbanisation is being accompanied by a process of decentralisation that affects both people and businesses (Lisowski 2007). And alongside the intensive generation of urbanised (mainly housing) land, there is the further phenomenon of the disappearance of the close link hitherto existing between construction work and the agricultural function, since inhabitants of this zone move out of agriculture, while the infrastructure of parts of the old farms is being adapted for other uses, as fieldwork makes clear.

The work carried out to determine changes in cover reveals that rural areas out to a distance of around $25 \mathrm{~km}$ from the centre of Warsaw display an overall trend for areas of land encompassed by the process of spatial and residential urbanisation to increase. This trend becomes less and less marked at greater distances, however. Beyond
$40 \mathrm{~km}$ from the centre of Warsaw, there is a considerable weakening of the influence distance is able to exert on changes in cover (Figs. 11, 17). In turn, the relatively limited increases in area characterising land close to Warsaw (up to around $20 \mathrm{~km}$ from the centre - Figs. 13, 19) may be linked up with the environmental/economic situation. In the first place, many gminas are witnessing a process whereby supplies of potential land for development are becoming exhausted - this being especially true of those in which forest cover and the share of protected land are high. Beyond that, there are the facts that land prices in these areas are much higher than at greater distances out from Warsaw, and that many owners have decided to leave farmland fallow and/or delay selling it in line with an assumption that sales will be even more lucrative later. A fourth factor concerns the large Warsaw hinterland in which land with a productive, service-related, storage or warehousing function has ceased to sustain activity in these categories, but continues to either represent a reserve for development, or be subject to new development and/or a renewal of activity. The areas in question have often been subject to a change of designated function, e.g. from the production-related to the residential, which does not influence the overall picture where changes in the areas of urbanised land are concerned. The very intensive development of urbanised (including also residential) land in zone II (at distances of 20-30 km), and the quite intensive development of this kind in zone III (at 30-40 km) and even zone IV (40-50 km) may be accounted for by reference to the relatively large supply of land and much lower prices than in zone I, as well as to an ongoing increase in the level of mobility of the populace, thanks to the proliferation of cars.

It has further proved possible to identify a new geographical direction to dynamic changes characterising the period from 2004 onwards. The most marked growth in the area of residential land has typified the area north of Warsaw, most especially some of the gminas along the Rivers Bug and Narew, as well as areas to the east of Warsaw, above all in the vicinity of Mińsk Mazowiecki (Fig. 16). These are thus directions different from those identified for the 2000-2004 period (Degórska \& Deręgowska 2008), at which time it was the areas to the east of Warsaw that were displaying the most limited dynamic for increased residential urbanisation, while a high dynamic mainly characterised areas to the south, south-west and west of 
Warsaw, as well as to a lesser degree the north. From 2004 onwards, the southern and western directions declined in significance, while the northern and eastern became far more important. Results obtained for the main directions to intensive spatial urbanisation thus differ from those determined by P. Korcelli et al. (2012), for whom the most major changes in the situation were continuing to affect a zone to the south of the Polish capital.

One factor encouraging or underpinning the development of residential areas to the north and north-west of Warsaw may be attractiveness of the landscape. The proximity of areas of forest and water to land not nevertheless embraced by the different forms of nature protection may represent an ever-more important attractor where the development of the housing function is concerned. In turn, the economic factors favouring the emergence of residential areas go beyond the obvious one of relatively cheap land in this part of the WMA to include the decision to construct a new airport for Warsaw now in operation at Modlin, this stimulating investment activity to the north and north-east of the capital. Further important conditioning may include changes in agricultural policy that have made it far more difficult than hitherto to exclude relatively fertile farmland from production, these potentially reducing pressure in the western and south-western directions. Today's areas of intensive development of urbanisation (including residential) are those on the poorer soils of land to the north-east and east of Warsaw.

The new areas associated in particular with the development of residential land do not now correlate solely with good transport access vis-à-vis the main routes into Warsaw (the latter factor being the main one determining the appearance of strip development of the Warsaw agglomeration up to the time of the systemic transformation). Rather, the economic factor, plus increased mobility and attractiveness from the landscape point of view have been what determine residential urbanisation, including at greater distances from Warsaw. New housing construction, as well as construction associated with the development of services, and with production or storage facilities, develop more and more often in areas solely accessible by car, and not served by public transport. The disappearance of the link between the urban growth and road access via the main routes in and out of cities has also been noted by Aguayo et al. (2007), albeit for Chile rather than Poland.
The favourable nature of the changes linked with the suburbanisation of rural areas reflects the improved quality of life in terms of housing conditions and the quality of the building that is taking place. However, no modification of the spatial order ensues, with the result that an amorphous space with features of non-sustainable development is created. Almost all of the rural units with a higher share of urbanised land are characterised by further shrinkage in forest cover. Post-2004, this trend unfavourable from the environmental point of view took in much larger areas than in the years 2000-2004 (Fig. 5), and it can be presumed that it will be maintained in the future. In conditions of more limited forest cover, the WMA may be brought to a situation in which the capacity of the region's green infrastructure to render "services" useful or vital to people as regards recreation, as well as bioclimatic and sanitary conditions, will be impinged upon more and more. There will also be more limited possibilities for the spatial structure of the ecological network to be optimised, especially by means of green belts. Overall, the process will bring about a further degradation of valuable features of the natural landscape in areas where these features ought to be kept in place for the benefit of future generations. It thus needs to be stressed that one of the more important socio-environmental goals included within the spatial policy for the WMA ought to be the designation and protection of a regional environmental network characterised by spatial cohesion.

There appears to be an absence of mechanisms to rein in an uncontrolled process of urban sprawl that now threatens sustainable development in the WMA, this reflecting a dynamic process of construction in open areas in Warsaw and its vicinity proceeding without a clearly defined - and binding - WMA-wide set of directions for development, as integrated with spatial policy at the level of each gmina (local authority) within the area. In the face of the absence of physical development plans for other areas, the same threat can be said to affect many urbanised areas in Poland.

Spatio-functional, architectural, aesthetic and environmental chaos plus exploitative land management do not favour the shaping of spatial order and a harmonious landscape, and nor do they favour protection of the environment. Indeed, urban sprawl is known for generating astronomical social, economic and environmental costs. 
Furthermore, the present spatial policies of most gminas favour urban sprawl, while ongoing suburbanisation is an inevitability in metropolitan areas in particular. The alternative that nevertheless exists entails an approach to sprawl that redirects spatial policy towards the shaping of a compact city first and foremost. The advantages of this are indicated by Chmielewski (2002) and Lorens (2003), among many others. The current state of land use in many cities of post-communist Europe entails there being many development sites either unutilised or capable of being freed up for new development, without green space being impinged upon at all, since the areas in question are designated for production or warehousing, are railway land or waste ground,

\section{References}

Аввотт C., 2002. Planning a sustainable city: The promise and performance of Portland's urban growth boundary. [in:] G.D. Squires (ed.), Urban sprawl: Causes, consequences \& policy responses, Washington D.C.: Urban Institute Press, pp. 207-235.

Aguayo M. I., Wiegand T., Azócar G. D., Wiegand K., VEGA C. E., 2007. Revealing the driving forces of midcities urban growth patterns using spatial modeling: A case study of Los Angeles, Chile. Ecology and Society, vol. 12, iss. 1, art. 13, http://www.ecologyandsociety.org/vol12/iss1/art13/ [23 September 2012].

Antrop M., 2004. Landscape change and the urbanization process in Europe. Landscape and Urban Planning, vol. 67, iss. 1-4, pp. 9-26.

Batty M., Besussi E., Chin N., 2003. Traffic, urban growth and suburban sprawl. Centre for advanced spatial analysis working paper series, paper 70, London: Centre for Advanced Spatial Analysis, University College, $12 \mathrm{pp}$.

Chmielewski J., 2002. Dezurbanizacja niweczy ład przestrzenny. Kwartalnik Architektury i Urbanistyki, vol. 47, iss. 3, pp. 243-250.

Chmielewski J.M., 2005. Problemy rozpraszania się zabudowy na obszarze metropolitalnym Warszawy. [in:] P. Lorens (ed.), Problem suburbanizacji, Biblioteka Urbanisty, vol. 7, Warszawa: Urbanista, pp. 52-62.

Cieslewicz D.J., 2002. The environmental impacts of sprawl. [in:] G.D. Squires (ed.), Urban sprawl: Causes, consequences \& policy responses, Washington D.C.: Urban Institute Press, pp. 23-28.

DegóRSKA B. 2003. Impact of the urban sprawl on environmental planning. Warsaw Metropolitan Region or consist of less-valuable farmland. These areas are not serving their primary or original functions, and they are yet further augmented by areas fully within urban zones in major need of revitalisation.

However, given the weaknesses in Poland's planning system, it would seem that the issue of the sustainable development of the Warsaw Metropolitan Area - including the curbing of urban sprawl - is and is likely to remain a very difficult area for spatial planning policy in this country.

Editors' note:

Unless otherwise stated, the sources of tables and figures are the author, on the basis of their own research.

in the context of European experiences. [in:] Society and environment. Towns and settlement in Europe, Europa XXI, vol. 10, Warszawa: Instytut Geografii i Przestrzennego Zagospodarowania PAN, pp. 51-60.

DegóRSKA B., 2004. Does the current spatial development of the metropolitan region of Warsaw conform to the precepts of sustainable development? [in:] J. Kitowski (ed.), Central and Eastern Europe at the threshold of the European Union - an opening balance, Geopolitical Studies, vol. 12, Warsaw: Institute of Geography and Spatial Organization PAS, University of Rzeszów, pp. 457-468.

DegǴRSKA B., 2007. Spontaniczny rozwój zabudowy na obszarze metropolitalnym Warszawy jako przykład istotnego problemu planowania przestrzennego, [in:] S. Kozłowski, P. Legutko-Kobus (eds.), Planowanie przestrzenne - szanse i zagrożenia społeczno-środowiskowe, Lublin: Katolicki Uniwersytet Lubelski Jana Pawła II, Lubelska Szkoła Biznesu Fundacji Rozwoju KUL, pp. 292-311.

DegórsKa B., 2009. Changes in the landscape of the Warsaw Metropolitan Area in the late 20th/early 21st centuries. Annual Report 2009. Polish Academy of Sciences, Warsaw: Office of Science Promotion, pp. 102105, http://www.english.pan.pl/images/stories/pliki/ publikacje/annual_report/AR_2009_miniPDF.pdf [26 october 2012].

Degórska B., 2012. Problemy planowania struktur przestrzennych Obszaru Metropolitalnego Warszawy zwiqzane z żywiołowa urbanizacja przestrzeni. Mazowsze. Studia Regionalne, vol. 10, Warszawa: Mazowieckie Biuro Planowania Regionalnego w Warszawie, pp. 89-106. 
DegóRSKA B., DeręGowska A., 2008. Zmiany krajobrazu Obszaru Metropolitalnego Warszawy na przełomie XX i XXI wieku. Atlas Warszawy, no. 10, Warszawa: Instytut Geografii i Przestrzennego Zagospodarowania PAN, $150 \mathrm{pp}$.

Fagan W.F., Meir E., Carroll S.S., Wu J., 2001. The ecology of urban landscapes: Modeling housing starts as a density-dependent colonization process. Landscape Ecology, vol. 16, no. 1, pp. 33-39.

GRUSzECKA K., 2005 Południowy obszar metropolitalny Warszawy. Ocena skutków trendów suburbanizacyjnych w latach 1991-2005. [in:] P. Lorens (ed.), Problem suburbanizacji, Biblioteka Urbanisty, vol. 7, Warszawa: Urbanista, pp. 157-162.

Gutry-Korycka M., Zegar T., Ostrowski W., 2005. The conversion of rural land to urban sprawl. [in:] M. Gutry-Korycka (ed.), Urban sprawl. Warsaw agglomeration case study, Warsaw: Warsaw University Press, pp. 53-82.

GzeLL S., 2002. Niezbędne warunki pozytywnych zmian krajobrazu strefy podmiejskiej. Architektura Krajobrazu, no. 1-2, Wrocław: Uniwersytet Przyrodniczy we Wrocławiu. Instytut Architektury i Krajobrazu, pp. 64-72.

Gzell S., Wośko-Czeranowska A., Majewska A., ŚwieŻEWSKA K., 2011. Miasto zwarte. Problem terenów granicznych. Urbanistyka. Międzyuczelniane Zeszyty Naukowe - Rok 2011, Warszawa: Akapit-DTP, 143 pp.

KomornickI T., ŚLESZYŃSKI P., 2009. Typologia obszarów wiejskich pod kątem powiqzań funkcjonalnych i relacji miasto-wieś. [in:] J. Bański (ed.), Analiza zróżnicowania i perspektyw rozwoju obszarów wiejskich w Polsce do 2015 roku, Studia Obszarów Wiejskich, vol. 16, Warszawa: Instytut Geografii i Przestrzennego Zagospodarowania PAN, Polskie Towarzystwo Geograficzne, pp. 9-37.

Korcelli P., Grochowski M., Kozubek E., Korcelli-OlejniCZAK E., Werner P., 2012. Development of urbanrural regions: From European to local perspective. Monografie, vol. 14, Warszawa: Instytut Geografii i Przestrzennego Zagospodarowania PAN, 158 pp.

Korwel-Lejkowska B., 2006. Propozycja metody oceny zmian krajobrazu spowodowanych rozprzestrzenianiem się miasta i jej zastosowanie w południowej części aglomeracji trójmiejskiej, [in:] S. Kozłowski (ed.), Żywiołowe rozprzestrzenianie się miast. Narastający problem aglomeracji miejskich w Polsce. Studia nad zrównoważonym rozwojem, vol. 2, Białystok: Wydawnictwo Ekonomia i Środowisko. pp. 265-282.

LIsowski A., 2005. Janusowe oblicze suburbanizacji. [in:] I. Jażdżewska (ed.), Współczesne procesy urbanizacji i ich skutki. XVIII Konwersatorium Wiedzy o Mieście, Łódź: Wydawnictwo Uniwersytetu Łódzkiego, pp. 91-100.
LISOWSKI A., 2007. The centralisation and decentralisation processes in the Warsaw Metropolitan Area in the years 1950, 2002. [in:] J.E. Klausen, P. Świaniewicz (eds.), Cities in City Regions. Governing the diversity, Warsaw: University of Warsaw. Faculty of Geography and Regional Studies, pp. 15-38.

LIsowski A., 2010. Suburbanizacja w Obszarze Metropolitalnym Warszawy. [in:] S. Ciok, P. Migoń (ed.), Przekształcenia struktur regionalnych. Aspekty społeczne, ekonomiczne i przyrodnicze, Wrocław: Instytut Geografii i Rozwoju Regionalnego. Uniwersytet Wrocławski, pp. 93-108.

LIsowski A., Grochowski M., 2008. Procesy suburbanizacji. Uwarunkowania, formy i konsekwencje. [in:] K. Saganowski, M. Zagrzejewska-Fiedorowicz, P. Żuber (ed.), Ekspertyzy do Koncepcji Przestrzennego Zagospodarowania Kraju 2008-2033. Tom 1, Warszawa: Ministerstwo Rozwoju Regionalnego, pp. 217-280, http://www.mrr.gov.pl/rozwoj_regionalny/poziom_krajowy/polska_polityka_przestrzenna/ prace_nad_KPZK_2008_2033/Documents/Lisowski.pdf [27 October 2012].

LORENS P., 2003. Zrównoważony rozwój a gospodarka przestrzenna. [in:] T. Borys (ed.), Zarzadzanie zrównoważonym rozwojem: Agenda 21 w Polsce - 10 lat po Rio, Białystok: Ekonomia i Środowisko, pp. 130-152.

LORENS P., 2005. Suburbanizacja w procesie rozwoju miasta postsocjalistycznego. [in:] P. Lorens (ed.), Problem suburbanizacji, Biblioteka Urbanisty, vol. 7, Warszawa: Urbanista, pp. 33-44.

MANTEY D., 2011. Żywiołowość lokalizacji osiedli mieszkaniowych na terenach wiejskich obszaru metropolitalnego Warszawy. Warszawa: Uniwersytet Warszawski. Wydział Geografii i Studiów Regionalnych, 189 pp.

Markowski T., Marszat T., 2006. Metropolie, obszary metropolitalne, metropolizacja. Problemy i pojęcia podstawowe. Warszawa: Komitet Przestrzennego Zagospodarowania Kraju PAN, 24 pp.

MBPR, 2010. Studium planu zagospodarowania przestrzennego obszaru metropolitalnego Warszawy. Warszawa: Mazowieckie Biuro Planowania Regionalnego w Warszawie, pp. 347, http://user.siskom.waw. $\mathrm{pl} /$ userftp/materialy/mat_dostepne/planistyka/studium_pzp_om_warszawy/studium_pzpomw_2010. pdf [20 October 2012].

NowaKowski M., 2006. Rozprzestrzenianie i rozpraszanie zabudowy warszawskiej metropolii. [in:] S. Kozłowski (ed.), Żywiołowe rozprzestrzenianie się miast. Narastajacy problem aglomeracji miejskich w Polsce, Studia nad Zrównoważonym Rozwojem, vol. 2, Białystok: Ekonomia i Środowisko, pp. 151-171.

RAVETZ J., 2000. City region 2020. Integrated planning for a sustainable environment. London: Earthscan Publications, 307 pp. 
Richardson H.W., BaE C.H.C. (eds.), 2004. Urban sprawl in Western Europe and the United States. Burlington: Ashgate Publishing Company, 325 pp.

Solon J., 2005. Landscape Diversity. [in:] M. GutryKorycka (ed.), Urban sprawl. Warsaw agglomeration case study, Warsaw: Warsaw University Press, pp. 265-296.

Solon J. 2009. Spatial context of urbanization: landscape pattern and changes between 1950 and 1990 in the Warsaw metropolitan area, Poland. Landscape and Urban Planning, vol. 93, no. 3-4, pp. 250-261.

Strzelecki Z., Holcel A., 2008. Tereny wiejskie Obszaru Metropolitalnego Warszawy. [in:] T. Markowski, Z. Strzelecki (eds.), Obszary urbanizacji i semiurbanizacji wsi polskiej a możliwości ich rozwoju w ramach PROW 2007-2013, Studia KPZK, vol. 119, Warszawa: Komitet Przestrzennego Zagospodarowania Kraju PAN, pp. 43-56.

StrzeleCKI Z., KuCińSKA M., 2006. Żywiołowe rozprzestrzenianie się metropolii warszawskiej. [in:] S. Kozłowski (ed.), Żywiołowe rozprzestrzenianie się miast. Narastajacy problem aglomeracji miejskich w Polsce, Studia nad Zrównoważonym Rozwojem, vol. 2, Białystok: Ekonomia i Środowisko, pp. 125-150.

ŚLESZYŃSKI P., 2012. Warszawa i Obszar Metropolitalny Warszawy a rozwój Mazowsza. Trendy Rozwojowe Mazowsza, no. 8, Warszawa: Mazowieckie Biuro Planowania Regionalnego, 160 pp.

TRZASKOWSKA E., SOBCZAK K., 2006. Jak chronić krajobraz wsi podmiejskich przed rozlewaniem się miast na przykładzie okolic Lublina. [in:] S. Kozłowski (ed.), Żywiołowe rozprzestrzenianie się miast. Narastający problem aglomeracji miejskich w Polsce, Studia nad Zrównoważonym Rozwojem, vol. 2, Białystok: Ekonomia i Środowisko, pp. 317-326.

ZGLIŃSKI W. 1994. Kształtowanie się strefy żywicielskiej aglomeracji warszawskiej. Prace Geograficzne, no. 162, Warszawa-Wrocław: Instytut Geografii i Przestrzennego Zagospodarowania PAN, Ossolineum, $164 \mathrm{pp}$.

ZUZIAK Z., 2005. Strefa podmiejska w architekturze miasta. [in:] P. Lorens (ed.), Problem suburbanizacji, Biblioteka Urbanisty, vol. 7, Warszawa: Urbanista, pp. 17-32. 